\title{
CHALLENGING THE SYSTEM? THE POTENTIAL FOR RADICAL POLITICS IN THE AGE OF FERGUSON
}

\author{
Danae Hart \\ Claremont Graduate University
}

In this article, I will put Cultural Studies scholarship, specifically different views on how hegemony functions within society, in conversation with the activism that has emerged within Ferguson, Missouri. The formation and solidification of activism networks within the small city occurred in the days succeeding the shooting death of the unarmed Black youth Michael Brown. My approach will focus on a discussion of hegemony and how it is maintained or reinforced through activism even if these acts are understood to be forms of resistance against the system. There is also activism that seems to work within the system or to be supportive of it that may in fact pose a significant challenge to hegemonic norms. I believe it is crucial to recognize hegemony's relationship to the activism that emerged after the failure to indict Darren Wilson specifically within the city of Ferguson in order to note how hegemonic constructs, seen in the failure to note the realities of the United States justice system, must be dismantled to create change. In the events during the aftermath of the death of Michael Brown at the hands of police officer Darren Wilson, the town of Ferguson, Missouri mobilized around the issue of injustice suffered by Black citizens within the justice system. Although the specific case's details were being discussed throughout the media, the essential aspect to understand about this case is how Brown became a symbol for the fight against police brutality. The murder of Michael Brown brought not only issues of race to the forefront, but directly challenged an important tenet within the system, the ability of the representatives of the justice system to carry out acts of violence that become justifiable through their relationship to the powers of the State. Debates centered around specific aspects of the case were engaged in to individualize the situation in order to avoid a dialogue about broader issues within the system as a whole that is only exemplified in the injustice of Brown's killer facing no legal consequences. This article will focus on how hegemony is challenged through acts of activism and understanding how some of the emerging activism may in fact reinforce hegemonic ideals. I will focus specifically on the creation of the activism network Hands Up United as a conglomerate of several different official and unofficial organizations, which emerged in the days following Brown's 
murder as well as the nationally recognized organization of the NAACP (National Association for the Advancement of Colored People) and their Justice for Michael Brown campaign. I will look at these activism efforts through a Cultural Studies lens to differentiate the ways in which hegemony is understood or viewed by them in order to better understand how they have attempted to forge a radical politics or have fallen short at challenging problematic dominant beliefs.

It is crucial to understand the ways in which hegemony is reproduced in order to challenge its perpetuation. Hegemonic norms are constructed and have become so easily reduced as "common sense," an established norm that should be undoubtedly accepted. This process can be recognized from the perspective of an activist in order to devise a strategy using similar tactics to circulate norms with the intention of disrupting dominant ideologies. According to Althusser, hegemonic ideals are naturalized through RSA's (repressive state apparatus) and ISA's (ideological state apparatus) in order to manufacture free consent. These forces use different tactics in order to establish hegemonic constructs even though the RSA's use outward displays of force in order to engrain hegemonic ideals. ISA's use a model that is very similar. Dominant norms are not perpetuated through the use of direct force (especially within ISA's) but instead are understood as an exercise of an individual's freedom or the choice to believe. This choice is seen as a result of free consent, but it is essential to understand how this consent is actually a product that has been manufactured through the use of RSA's as well as ISA's. The justice system is connected to both RSA's and ISA's because it is represented through police forces (RSA) and the legislative branch of the government (ISA). Even though police brutality is what is being challenged through these activism efforts, the existence of violent strategies in the exchange between officers and citizens is a necessary component of the way in which the justice system operates. The problems in the justice system go far beyond just the police forces, but are seen within every aspect of the justice system that results in treatment that is unequal for Black citizens. The problem is not just within police officers' discriminatory practices, which is seen by Darren Wilson feeling completely justified in confronting Michael Brown without any knowledge of any wrongdoing, but continues within the legal system as seen through the failure to indict Wilson for his decision to use deadly force on an unarmed citizen. Michelle Alexander notes the widespread issues within the system, "Judges are just as reluctant to second-guess an officer's motives as they are to second-guess prosecutors'. So long as officers refrain from uttering racial epithets and so long as they show the good sense not to say 'the only reason I stopped him was 'cause he was black,' courts generally turn a blind eye to patterns of discrimination by the police" 
(Alexander, 133). The legal language perpetuated through ISA's is constructed to treat Black citizens only as criminals, but has evolved past the use of racial language in order to hide the explicit racial implications of the application of the law.

How the RSA's and ISA's converge in order to perpetuate hegemonic ideals as seen through the operation of the justice system is a critical aspect of the maintenance of hegemony. Althusser argues, "To my knowledge no class can hold State power over a long period without at the same time exercising its hegemony over and in the State Ideological Apparatuses" (Althusser 146). The justice system is heavily invested in state ideological apparatuses and is often viewed as synonymous with the state itself. As Althusser notes the ability to hold this power is seen within the naturalization of roles illustrated by the societal need for children to attend school regularly as necessary to reproduce a system of labor. This same naturalization is seen in citizens' relationship to the justice system as a necessary force to combat harm or the fear of harm within our society. The concept of the necessity of police forces within all communities, the belief that penitentiaries are necessary to deal with citizens who engage in transgressive behaviors, and the ability of the system to dictate what behavior should be criminalized in order to maintain peace or order, are just a few of the naturalized concepts the justice system relies on as a means of sustaining hegemonic normative constructs.

Althusser continues with the example of the school as an ISA and how it functions, "In other words the school teaches 'know-how', but in forms which ensure subjection to the ruling ideology or the mastery of its 'practice" "(Althusser, 133). Hegemonic power is maintained through reproduction (often unknowingly) of the system through a perpetuation of normative practices that are not challenged because they have become naturalized. The naturalization of the oppressive tactics utilized by the justice system is what Michelle Alexander is challenging in her book The New Jim Crow: Mass Incarceration in the Age of Colorblindness by highlighting how racism is a necessary component of the justice system as it works today. Alexander argues, "What is painfully obvious when one steps back from individual cases and specific policies is that the system of mass incarceration operates with stunning efficiency to sweep people of color off the streets, lock them in cages, and release them into inferior second-class status" (Alexander 103). I believe Alexander would be highly critical of the demands created by the NAACP and Hands Up United as being too focused upon an individual case without noting how the construct of criminalization must be dismantled in order to fully understand the problems inherent in the justice system. Failing to question the justice system as a whole and deciding to work within the constructs 
of the system is often believed to be the easiest route to achieve progress, but it fails to note how incidents should be understood in the context of a larger system. Advocating to work within the system not only comes from organizations such as the NAACP where it may be expected, but is seen even within the on- the-ground mobilization occurring in the wake of the grand jury decision to not indict Darren Wilson. The role of the justice system is not questioned and is represented as natural even within the organization Hands Up United's list of demands, which focus on achieving some form of prosecution through the justice system. The list of demands is split between two different categories, the "local demands" focusing specifically on the actions of Darren Wilson and the St. Louis Police Department, and the "national demands" they see as applicable to the entire nation to address this issue. The local demands include actions such as the "Immediate arrest of Darren Wilson, the firing of Ferguson Police Chief Thomas Jackson, and the immediate release of individuals who have exercised their rights to assemble and protest" (Hands Up). The national demands include: "Obama to come to Ferguson to meet with the people whose human rights have been violated by aggressive and militarized policing, including the family of the victim Michael Brown and the immediate suspension without pay of law enforcement officers that have used or approved excessive use of force. Additionally, their names and policing history should be made available to the public" (Hands Up). This reliance on the perpetuation of the normalization of the justice system has been utilized as a tactic in order to challenge hegemonic norms through a method in which they are rearticulated in a manner that calls for citizens to overconform to the current ideologies. The role of the justice system as a necessary construct to attain peace and order within the state is reinforced through the activism that calls for justice according to its socially constructed meaning that centers around the methods utilized by legal forces. Activists are calling for justice through a conviction of Darren Wilson and the reliance on an understanding of justice that works within the system because it is the very system and mentality that has been used to oppress them.

Gramsci notes how hegemony is maintained through a "spontaneous consent" as well as the coercive power of the State. This two prong understanding of hegemonic forces mirrors Althusser's conceptual formation, but Gramsci contrasts with Althusser in his discussion of human agency within this process. Gramsci also does not see hegemony as a uniform set of beliefs that is internalized by the ruling class, but folklore beliefs that are intended to be circulated. An example of this is the folkloric belief that cops are within communities to protect and to serve. This constructed motto is something repeated and highly circulated, but is not 
necessarily internalized as an accepted truth by all who continue to further the ideal.

Gramsci expands on how he sees hegemonic ideals being perpetuated beyond the circulation of folklore beliefs based upon what he terms as a dialectic. Hegemony is maintained only through a dialectic process between the masses and ruling class (not only reliant upon suppression). Through the acknowledgment of a dialectic process, Gramsci does note a level of human agency within the structuring or the maintenance of hegemonic norms within society. According to Gramsci, there is also a dialectic that mirrors this, but it instead notes the dialogue that occurs. As Gramsci argues, "The process of development is tied to a dialectic between the masses and the intellectuals" (Gramsci 334). In understanding human agency, we are able to recognize how to overcome hegemonic forces through understanding the ways in which they are developed. Gramsci does not see freedom or the ability to overcome these constructs as being achieved through willingly giving it up, as Althusser notes, but instead through the use of the organic intellectuals who emerge within each class and their ability to influence change through communication with traditional intellectuals of the ruling group (hegemonic forces). Gramsci notes: "One of the most important characteristics of any group that is developing towards dominance is its struggle to assimilate and to conquer 'ideologically' the traditional intellectuals, but this assimilation and conquest is made quicker and more efficacious the more the group in question succeeds in simultaneously elaborating its own organic intellectuals" (Gramsci 10). Gramsci asserts that subaltern groups can gain access to aspects of power that belong to the hegemonic group through organic intellectuals. The group Hands Up United could be understood as an example of organic intellectuals within their community in a collective sense of the term as Gramsci notes that organic intellectuals arise within all classes and are able to mobilize around central issues in their community. Hands Up United constructed their demands as a coalition of several different groups, they note: "This is a reflection of the local demands as expressed by local organizations leading on the ground in Ferguson, such as Organization for Black Struggle, Missourians Organizing for Reform and Empowerment, and others. The National Demands reflect demands developed by organizations such as Freedom Side, Dream Defenders and Color of Change" (Hands Up). In the case of Hands Up United, they are seeking entrance to the power held by the hegemonic group, which is the power to seek some form of justice within the federal justice system as it stands (Hands Up United). They are advocating for demands that are in line with the desires of the dominant group rather than in opposition to it. Both Hands Up United and the NAACP are fighting for an investigation that they deem to be fair in order to conform 
to hegemonic understandings of how justice is achieved as a result of the perpetration of a crime.

The NAACP's Justice for Michael Brown campaign is centered upon the demand for the FBI to take up the case against Darren Wilson arguing that the local police department's mismanagement of the situation is what stands in the way of a fair investigation with a fair outcome (NAACP). This response does not appear to challenge hegemonic forces or dominant ideology and seems to only be advocating for the current system to work more efficiently. The Justice for Michael Brown campaign developed by the NAACP calls for confidence in the belief that the system has the ability to work for everyone and that the injustice suffered is a result of a lack of adherence to the structure rather than the system's inadequacy to properly address issues such as this. The campaign states:

It became clear very early on that the St. Louis County Police Department was dragging their feet in the case. Instead of collecting information, they confiscated cell phones and starting acting as an invading military. Instead of talking to witnesses and members of the community, they fired tear gas and rubber bullets at those seeking answers. The NAACP petitioned the FBI to take up the case in Ferguson to ensure a full, unencumbered investigation into Michael Brown's death would take place. We have been working with them to collect information and to provide a safe place for members of the community to come forward and be heard. (NAACP)

The actions of the St. Louis Police Department are not discussed as behavior exhibited by other precincts, but individualized as a failed approach instead of a discussion of how these tactics are seen nationally or contribute to a pattern that should be addressed. The NAACP calling on the FBI to investigate is in alignment with Zizek's views on over-conformity as a form of challenging the system as a whole. As Zizek notes, transgressions are themselves part of the system. To truly challenge hegemony or to be subversive there is a need to take the system seriously and more seriously than it takes itself (Zizek). Zizek's concept of overconformity is represented by the NAACP's belief that the FBI could police the local police departments and intervene in order to right the flawed investigation and bring about justice by calling for the system to maintain norms at all times (regardless of the victim's race) as the only way to challenge the operation of the justice system. The NAACP is known for their campaigns to encourage Black citizens to vote in order to create change. They have advocated to work within the system to achieve reform within it. This is seen within the campaigns the NAACP has launched in recent years. One of the last campaigns was aimed at ad- 
dressing the racial profiling prevalent in New York City that was deemed completely legal as a result of the stop and frisk laws. They fought for a solution firmly located within the confines of the justice system and, as their website notes, they were able to achieve the goals they set to address: "In 2013 the New York City Council passed, over a mayoral veto, laws that ban racial, ethnic and gender profiling and hold the city accountable for abuses. The campaign also helped to dissuade San Francisco's mayor from adopting the practice in his city" (NAACP). This victory does not truly put an end to racial profiling, but it is a start to confronting hegemonic norms, which is what they aim to accomplish in the Justice for Michael Brown campaign as well. In an update from August 14, 2014, during the campaign's early days, the group wrote: "Today, the St. Louis branch will meet with Thomas Jackson, Chief of Police of the highly segregated Ferguson Police Department, to demand an end to the militarized tactics of his department in the Ferguson community" (NAACP). The resistance they have constructed is based upon the creation of a dialogue between themselves and the justice system, which strengthens their perception of the justice system as legitimate rather than questioning it. The NAACP furthers the belief that change should be and ultimately can be achieved through working within the system to directly combat its role in their oppression.

Stuart Hall believes the key to challenging hegemony lies not within giving up freedom (as Althusser would argue) or necessarily within the organic intellectuals of the class (Gramscian concept), but lies within altering the meaning of signifiers through dislocation outside of the existing structures. Hall sees the struggle through re-articulation with the possibility of achieving new meanings. The limitation of the meanings of signifiers structures the problems within media representations that rely on these signifiers to convey meanings, which conforms to hegemonic rhetoric. The way in which race is a signifier of crime is seen throughout the news media regardless of the context or organization presenting the story. Michelle Alexander argues, "In fact, for nearly three decades, news stories regarding virtually all street crime have disproportionately featured African American offenders. One study suggests that the standard crime news 'script' is so prevalent and so thoroughly racialized that viewers imagine a black perpetrator even when none exists" (Alexander 106). Hall sees the possibility of challenging the hegemonic ideals encoded within the media through the manner in which it is decoded through negotiated or oppositional readings (Hall). Even though the racial bias is seen within news stories depicting crime, there is power in the ability of people to decode these stories in negotiated or oppositional manners. "One of the most significant political moments is the point when events which are normally signified and decoded in a negotiated 
way begin to be given an oppositional reading" (Hall 61). Hall argues there is a political nature to oppositional readings by countering hegemonic ideals, but Zizek would disagree with the belief that this opposition truly challenges the system. An oppositional reading to a common signifier was used by the organization Hands Up United through the gesture of raising your hands seemingly in accordance to officer's commands (Hands Up). The group choose to use this image in an oppositional way by using this gesture as a means of conveying how Black citizens are always in fear of police action and always treated as criminals regardless of the context. The criminalization of people of color is a core function of the justice system as it operates today; not an unfortunate consequence or side effect of its implementation. Black people stand outside of the dominant construction of citizen and are not constituted as those who can benefit by having the ability to seek justice in the hegemonic conceptions of the law as it exists today. The signifier of raising up their hands is a gesture of surrendering that applies to the activist's stance toward police brutality as well as how they desire to end the conflict between their community and the police force. The activists do not wish to fight or challenge the officers, but intend to make it clear that they desire full citizenship that allows them the ability to seek justice within the very system that has challenged their subjectivity through criminalization. The gesture of placing their hands up requires the knowledge of hegemonic definitions in order to formulate a new understanding of our justice system to counter dominant ideology. This dislocates a signifier in order to place it within a new context providing new possibilities for people of color to challenge the ways in which they are criminalized and be viewed as true worthy citizens.

Hegemony is not stable or fixed, it must be maintained. Even though Althusser and Gramsci have a similar understanding of how hegemonic ideals are perpetuated, they differ in recognizing how to overcome this. Gramsci argues hegemonic power can be obtained by subaltern groups through the organic intellectuals of a class having the ability to challenge traditional intellectuals or those belonging to the dominant group, which expands the understandings of human agency. In Gramsci's view, Hands Up United (as a coalition of activists from different regions and different areas of expertise) are representative of organic intellectuals coming together to formulate theories for change. In this vein, through their activism efforts, they may be able to gain access to the notions of hegemony that they wish to attain in the form of a fair trial and investigation into the murder of Michael Brown. They must successfully challenge the intellectuals of the dominant group in order to attain this power as organic intellectuals. Hall, similar to Gramsci, argues for the need to challenge hegemonic ideals, but believes the key to stopping 
the reproduction of hegemony is through the decoding process. Hall sees the power being held through collective oppositional readings to challenge the system, which may be seen as the work of organic intellectuals within their respective classes outside of the dominant group. If Hands Up United is a project undertaken by organic intellectuals, their use of the hands up gesture is how they implement an oppositional reading. The concept of organic intellectuals and the concept of applying oppositional readings to signifiers attributed to a dominant meaning should not be viewed as two exclusive conceptions on how to challenge hegemony, but should be understood as an interconnected means to create reform. Both Hall and, to a lesser extent, Gramsci speak to the ability of individuals to challenge hegemony through the practice of decoding or the construction of organic intellectuals respectively. Although, I would argue that Hands Up United does not see their mission as truly challenging hegemonic norms, but instead aims to draw attention to how the hegemonic constructions of the justice system function differently for Black citizens in order to rectify this disparity.

The movement created through the formation of these activism networks challenging aspects of the justice system emerged through a shared conception of common sense among people of color. As Hall would note, as members of a subaltern group they developed a common sense that is inherently skeptical of law enforcement because of the widespread knowledge of the RSA's abuse of power. The question then arises how can groups come forth to protest the actions of officers as individuals without a larger discussion of the justice system as a whole. Acknowledging the wrongful acts of one particular officer could be a form of a negotiated reading that does not seek to challenge dominant conceptions of the justice system as an institution, but tackles a problem that can be individualized. In many ways the NAACP engaged in a negotiated reading by specifically pinpointing the St. Louis Police Department for conducting an inadequate investigation and by questioning that department's tactics when dealing with activists. They particularly described the problem as one within this one local police department rather than acknowledging how often problems such as these plague Black communities throughout the nation and beyond it. Through this lens they would not question or seek to dismantle the justice system as it currently stands but push for some reform while working within the confines of the system. The confines of the system were shown through the NAACP's reliance on already established legal forces which they wanted to prioritize the investigation and called for a federal intervention that still exists within the structures of the system.

Preferred readings deem Brown's death as justifiable homicide through its legitimization through an apparatus of the State which wields 
the ability to engage in these transgressions of the law because of their status as representative of it. A dominant understanding of the event is that Michael Brown is denied full citizenship and the rights thereof and presented an immediate threat to the law or to Wilson, who is merely the actor carrying out the actions the system deems to be necessary. Under a preferred reading there is often a desire to erase the aspect of race or relegate it to an unnecessary detail in what occurred. Within dominant readings there is a reliance on color blind language and the belief that racial inequality is a symbol of the past that we have progressed beyond. "The story that is told during Black History Month is one of triumph; the system of racial caste is officially dead and buried. Suggestions to the contrary are frequently met with shocked disbelief" (Alexander 21). The insistence on a post racial society within dominant constructions is exactly what the activism in Ferguson seeks to address rather than to continue to sweep these issues under the rug through the fear that they are too large to tackle.

The activism in the aftermath of Ferguson seeks to address the problems of the justice system, but the rhetoric used often reinforces hegemonic ideals, begging the question if change can be achieved without engaging in more critical discourse that seeks answers outside of the limitations of the current justice system. A downfall seen within the activism is that the problems within Ferguson are not often contextualized enough within significant critiques of the justice system beyond police brutality, such as the prison industrial complex or disparities in sentencing. There are a multitude of ways in which the justice system is used as an instrument of oppression upon the bodies of Black citizens that goes far beyond the poor decisions made by the St. Louis Police Department or the murderous impulse of the lone Darren Wilson. The violence Wilson enacted has become normalized as a method of dealing with all who are considered criminal through the dominant conceptions of criminal behavior and Black people are inherently criminalized regardless of their actual behavior. The use of deadly force is not questioned, but the focus is placed only on whether the victim was deemed a criminal. Due to the criminalization of Black people, they are not only vulnerable to acts of State violence, which would be ruled as justifiable in a legal sense, but Black people are also seen outside of dominant understandings of who is able to constitute a law abiding citizen that the justice system is constructed to protect and serve.

Can Hands Up United truly challenge hegemonic understandings of the law or is it a better strategy to argue within hegemonic constructs through politicizing oppositional readings? Perhaps the answer lies with Hall and Zizek being put into conversation with one another because rearticulation (and the way in which Hands Up United utilized this con- 
cept) is a form of over-conformitivity. Race as a signifier has been displaced in order to overconform to the dominant conception of the justice system in an attempt to seek all the privileges afforded to whiteness within the system. It is crucial to dismantle the belief that unjust treatment is not a result of racial bias that is an inherent part of the system rather than a result of when the law is transgressed. It is not a transgression of the law for Darren Wilson to murder Michael Brown without any legal consequence; it is how the justice system is constructed to operate. As seen by the NAACP's official stance on the failure to indict Darren Wilson, there is a need to seek justice through a commitment to the system and this must be done through the dislocation of the signifier race as well as how it is viewed within the justice system. Both the NAACP and Hands Up United have aimed to confront hegemonic norms and successfully create a movement that understands the significance of reform. Hands Up United and the NAACP understand the widespread and diverse issues facing Black communities throughout the nation, but want to acknowledge how these issues are interconnected as a result of society's institutions as well as the lived experiences of Black citizens. As Hands Up United explains, "As we work toward justice for the Brown family, we must also address the ongoing systemic problems of police practices in black, brown and all oppressed communities. We come together as diverse organizations to speak with one voice, so that the greater St. Louis area can become a model for justice for all across the United States" (Hands Up). Although there are conflicting theories on how to best initiate reform and how best to confront the problems that are entrenched within the justice system, they have constructed campaigns that highlight the disparities faced by people of color to successfully gain awareness as well as a consciousness to lead to action.

\section{Works Cited}

Alexander, Michelle. The New Jim Crow: Mass Incarceration in the Age of Colorblindness. New York: New, 2010. Print.

Althusser, Louis. "Ideology and Ideological State Apparatuses (Notes Toward an Investigation)." Lenin and Philosophy, and Other Essays. New York: Monthly Review, 1972. 127-86. Print.

Gramsci, Antonio, Quintin Hoare, and Geoffrey Nowell-Smith. Selections from the Prison Notebooks of Antonio Gramsci. New York: International, 1972. Print.

Hall, Stuart. "Encoding/Decoding." Media Studies: A Reader. By Paul Marris and Sue Thornham. 2nd ed. New York: New York UP, 2000. 51-61. Print. 
Hall, Stuart. "Signification, Representation, Ideology: Althusser and the Post-structuralist Debates." Critical Studies in Mass Communication 2.2 (1985): 91-114. Web. 28 Sept. 2014.

"Hands Up United Demands." Hands Up United. Hands Up United, 2014. Web. 08 Nov. 2014.

"Justice for Michael Brown." NAACP. National Association for the Advancement of Colored People, 14 Aug. 2014. Web. 9 Nov. 2014.

Upsidown13. "What the Hell Is Laibach All About?" YouTube. YouTube, 11 Mar. 2009. Web. 23 Oct. 2014.

Žižek, Slavoj, ed. The plague of fantasies. Verso, 1997. 